\title{
GREEN ICT POLICY MATURITy For ACTUAlization Of Sustainable CoMputing IN DEVELOPING NATIONS
}

\author{
Franklin Wabwoba \\ Kibabii University, Department of Information Technology
}

\begin{abstract}
Green ICT Policy encompasses the frameworks an organization has developed and put in place to apply environmental sustainability criteria throughout its value chain. The lack of appropriate green policy alignment to application of ICT uptake challenges the reaping of the benefits often stated of ICT. Multiple case study design with case from different sectors of the economy selected based on information richness, accessibility, size as well as diversity in application of ICT was employed. Triangulation of data collection and findings interpretation was utilised. The study established that green ICT policy maturity was very low. In effect, calling for purposed policy set up on green ICT application by developing nations to ensure ICT benefits are realised while limiting environmental degradation.
\end{abstract}

\section{INDEX TERMS}

Carbon footprint, Environmental responsibility, green ICT policy, green ICT policy maturity

\section{INTRODUCTION}

Green ICT Policy is the framework an organization has developed and implemented to in order to be able attain environmental sustainability throughout all its value chain. This is inclusive of the ICT sourcing, operations and services and end-of-life management (Cooper \& Molla, 2010); (Rao \& Holt, 2005). Green Policy can be considered to be about the green ICT initiatives administration, budget allocation, and other resources as well as the metrics that would be employed to assessing its impact (Cooper \& Molla, 2012). According Philipson (2010), a policy development framework would have to address issues of policies establishment, their communication, their enforcement, and the measurement of their effectiveness and mitigation strategies. A good green ICT policy therefore has to handle fairly comprehensively the roles and responsibilities, skill-sets, commitments, targets, deliverables and methodologies used. They need to precisely predict how an organisation is commitment to managing technology redundancy and the roll-over in a way that make the organisation to gain from the benefits by technology advancement that is rapidly changing.

Such green ICT policies would encompasses the frameworks that an organisation would institute in the application of the green ICT activities and operations environmental criteria (Molla, Cooper, \& Pittayachawan, 2009). Through this measure an organisations would be able to determine how advanced their green ICT initiatives have been undertaken. On such a basis, green ICT readiness may be assessed. The main areas for assessment of policy readiness according to 
Molla and Cooper (2009) include IT sourcing, IT operations and services and IT end of life management. Green ICT readiness policies can, therefore, be considered to be those that are designed to discourage environmental negative impacts. Such good green ICT policies would be designed to mitigate negative impacts in areas of energy intensive production methods, wasteful packaging, poor recycling practice and heavy hazardous materials use and practices.

Operations and services policy considerations are inclusive of computer power management and computer use policies for the staff. This includes of policies that guide the extent to which services provided by ICT support issues of sustainability (Molla, Cooper, \& Pittayachawan, 2009). IT end of life policy are policies and regulations that guide disposal and settlement of ICT infrastructure. Having IT end life policies and regulations at the national level will assist organisation to correctly manage ICT equipment that is no longer in use. Such a policy would lead to ICT trainers preparing learners for the future work force with a different approach that would lay emphasis on behavior change towards increased utilization of green ICT.

According to Munyua (Munyua, 2010), Kenya faces serious environmental problems due to increasing hazardous waste from electronic equipment that are mainly ICT infrastructure. Interestingly the country has no climate change policy. In fact the greatest challenge within the country is that the laws, legislations, policies and regulations existent are not well coordinated and are found in so many different documents. This makes it hard for people to be conversant with them. The National Environmental Management Authority (NEMA) that is responsible of all policies and regulations relating to the environment is yet to comprehensively set up regulations to actualize green computing, however, the Kenya ICT policy of 2006 has a clause on disposal and management of e-waste.

Following the lack of any comprehensive regulations in the nation with regard to green computing therefore calls upon every organisation to be proactive to come up with green ICT policy applicable to its operations. Such policies need to pay attention to areas such as Green data centre, shifting to green sources of energy, use of ICT reduce carbon footprint, environmentally friendly purchasing, employees use of ICT in an energy efficient manner, green supply chain management, end of ICT life management, corporate social responsibility and environmental sustainability (Wabwoba et al., 2013)

\section{Methodology}

A multiple case study which was the preferred option for this study referred to conducting several case studies (Yin, 2009) and this implied several holistic cases in which each holistic case consisted of only one unit of analysis. The multi-case study strategy allowed the study to retain the holistic and meaningful characteristics of real-life events at the centre of the study (hardware and software, individuals, organisational and managerial processes life cycles to mention but a few (Yin, 2009); (Kasomo, 2007); (Al Qur'an, 2010). The multi-case was chosen for this study since it provides robust and rigorous grounds for good quality research derived from triangulation of evidence (Yin, 2009); (Baxter \& Jack, 2008); (Al Qur'an, 2010).

Experienced researchers are in agreement that selection of cases should be based on purposive theoretical sampling (Eisenhardt, 1989); (Patton, 1990); (Perry, 1998); (Kasomo, 2007); (A1 Qur'an, 2010). For this study, four cases were selected based information richness, accessibility, largeness, leading, diversity in applications and the well-establishment in their respective sectors 
while balancing between urban and rural settings. One organisation was selected from each of the four sectors for the study: the university which train ICT manpower, the sugar manufacturing industry, government county offices and the ICT Regulator by virtue of the application of ICT in many different functional units in the day to day activities ranging from the core business to none core business.

Data was collected via interview, questionnaire, focused groups, observation, and documentation analysis. This allowed for triangulation of results to increase their credibility. Each case study was considered as a single unit of analysis so that flexibility and elasticity that distinguished semi-structured interviews that allowed for changing and modifying interview questions when need arises.

The study ensured the truthfulness, accurateness and replication possibility of the study in a number of approaches. The major validity observed in this study was construct validity, internal validity and external validity.

Construct validity was fulfilled by designing case study questions and asking questions during the interview and using multiple sources of evidence (triangulation) (Rowley, 2002); (Yin, 2009); (Al Qur'an, 2010). Internal validity / credibility were fulfilled through pattern-matching by matching and contrasting the emerging themes during data analysis with established themes in the existing literature reviewed (Rowley, 2002); (Yin, 2009); (Al Qur'an, 2010). In this study a combination of secondary data, observation and interviews were used. Secondary data in particular was used to inform and verify the findings. Another way of increasing the validity consisted of showing the research participants a summary of the findings for their interpretation. This took place in the field research and significantly, subjects were contacted where necessary to clarify data gathered and verify research findings.

External validity or generalization or transferability was fulfilled through use of replication logic in the multiple case design (Yin, 2009) whereby the findings from the selected case studies were replicated, adopted with purposeful sampling in selecting the case studies (Patton, 1990), writing rich-information case study report for data of each case (Bryne, 2001); (Al Qur'an, 2010) and by the use of multiple case design itself in which all selected cases were organisations from Kenya and representing four different sectors.

Generalisability was be enhanced by studying the same issue in four different research sites, using similar methods of data collection and analysis (Kothari, 2007). The possibility of studying numerous heterogeneous sites made multi-site studies a potentially useful approach to increasing the generalisability of the qualitative work.

Reliability was achieved through all selected cases and participants being subjected to the same entry and exit procedures (Yin, 2009), intensive documentation and appropriate recording keeping (Bryne, 2001); (Yin, 2009); (Al Qur'an, 2010) and in-depth interviews with participants and follow up as well as involving them in conclusions drawn for clarification.

\section{FINDINGS AND DISCUSSION}

The policy maturity levels in Kenya were assessed within the elements of green ICT, green data centre, shifting to green sources of energy, use of ICT to reduce carbon footprint, and 
environmentally friendly purchasing. The other aspects assessed included employees use of ICT in an energy efficient manner, green supply chain management, end of ICT life management, corporate social responsibility and environmental sustainability policies.

The findings of the assessment on the policy maturity are presented in Figure 1 and Figure 2

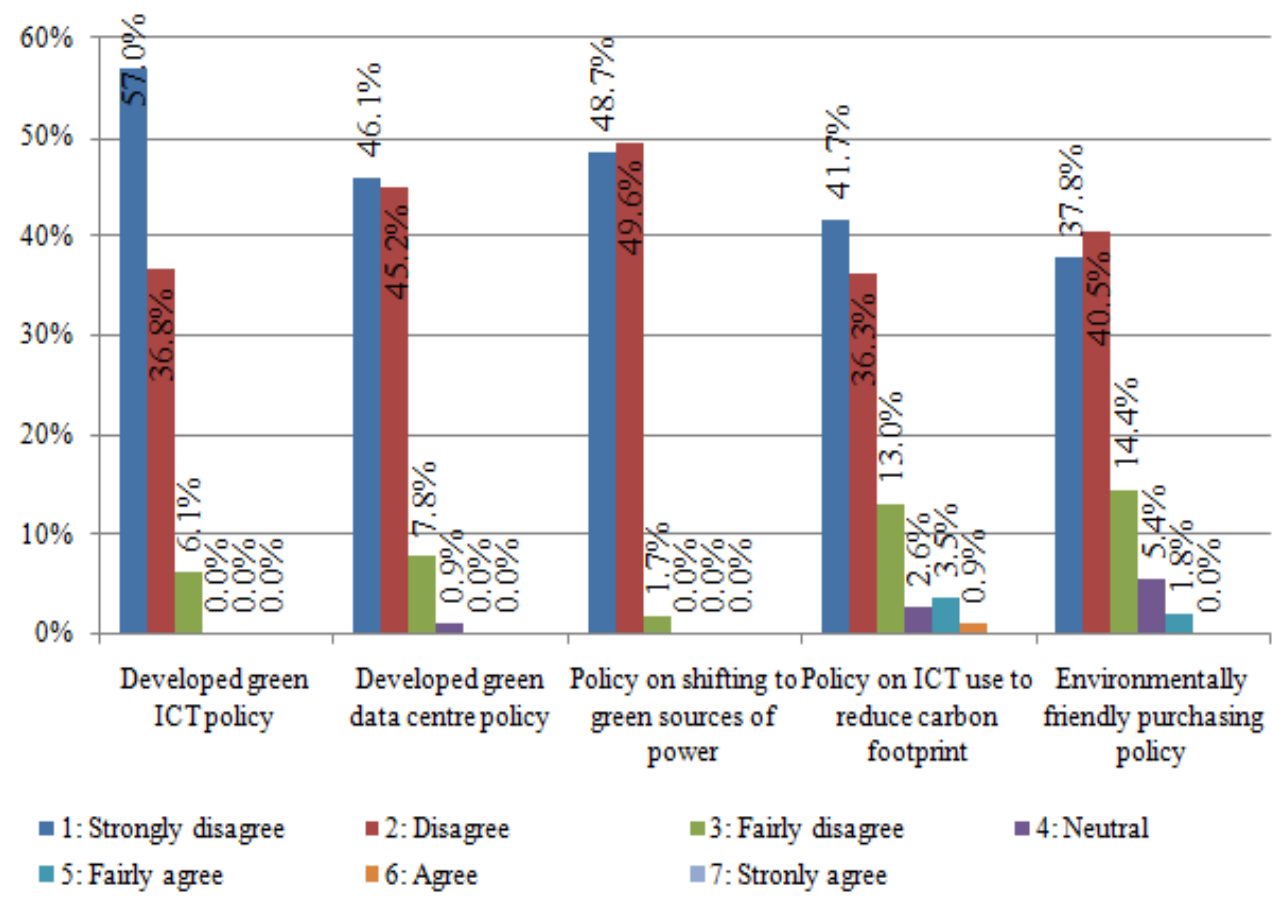

Figure 1: Policy Maturity (a)

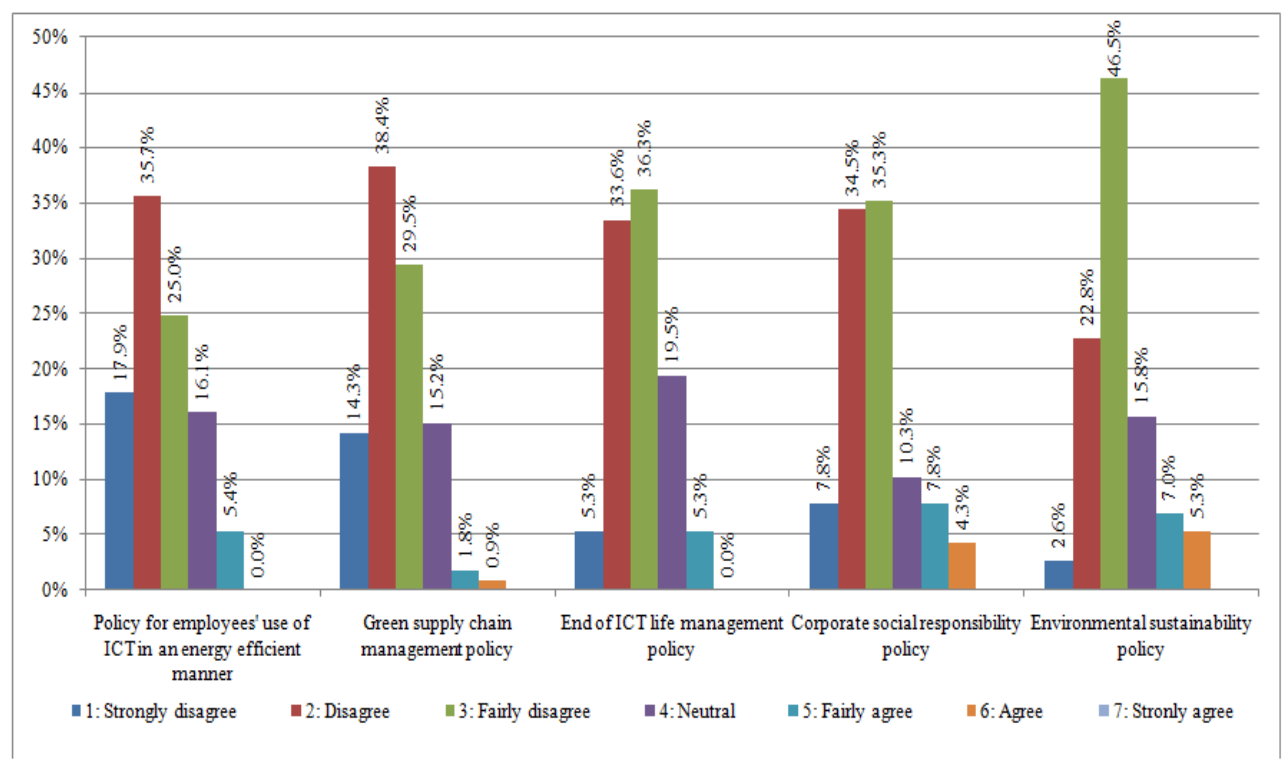

Figure 2: Policy maturity (b) 
Green ICT policy maturity plays a major role on how green ICT is implemented. From Figure 1 column $1,57 \%$ of the respondents strongly disagreed while $36.8 \%$ disagreed and $6.1 \%$ fairly disagreed with there being any green ICT policy within their organizations. This finding correlates with the responses obtained in the interviews with respondents who majorly acknowledged that no such a policy existed in the organisation. Hardly did any respondents produce a copy of a green ICT policy document. A number provided copies of the national ICT policy that only makes mention of green ICT. This implies that organizations do not have green ICT policies and if it existed then it was not clear to the personnel. Lack of such a policy is likely to limit the implementation of green ICT as members may not be sure of what to use to support their action.

Green data centre policy maturity analysis of findings presented in Figure 1 column 2 indicated that $46.1 \%$ (strongly disagreed) of the respondents believe their organisations to not have a developed data centre policy. At the same time $45.2 \%$ of the respodents disagreed to the existence of a data centre policy in their organisations while $7.8 \%$ fairly disagreed. Amongst the respondents a balance of $0.9 \%$ remained nuetral. Given the high percentage of responendts being of the opinion that there is no green data centre policy, there are minimal chance of green ICT being implemented within the data centres.

According to the findings in Figure 1 column 3, 48.7\% (strongly disagreed) of the respondents are of the opinion that their organisations to not have a developed policy on shifting to green sources of power. At the same time $49.6 \%$ of the respodents disagreed to existence of a policy on shifting to green sources of power in their organisations while $1.7 \%$ fairly disagreed. With virtually all the respondents disagreeing to there being such a policy, the chances that organisations are shifting towards green power sources are minimal.

The policy maturity on the use of ICT to reduce carbon footprint was sought in this study. Findings presented in Figure 1 column 4 show that $41.7 \%$ (strongly disagreed) of the respondents believe their organisations to not have a policy on ICT use to reduce carbon footprint. At the same time, $38.3 \%$ of the respodents disagreed to there being a policy on ICT use to reduce carbon footprint in their organisations while $13 \%$ fairly disagreed. Amongst the respondents $2.6 \%$ remained nuetral while $3.5 \%$ fairly agreed and $0.9 \%$ agreed to their organisations having a policy on ICT use to reduce carbon footprint. This finding correlates with the responses obtained in the interviews with respondents who majorly accepted that they did not have such a policy in the organisation. The lack of a policy to reduce carbon footprint leads to lack of effort towards reduction of the carbon footprint.

From findings in Figure 1 column 5, it is apparent that $37.8 \%$ of the respondents strongly believe that their organisations do not have a developed environmentally friendly purchase policy. At the same time $40.5 \%$ of the respodents disagreed to there being an environmentally friendly purchase policy in their organisations while $14.4 \%$ fairly disagreed. Amongst the respondents $5.4 \%$ remained nuetral and $1.8 \%$ fairly agreed that their organisations had a developed environmentally friendly purchase policy. However, looking at the shape in Figure 1 column 5, it can be observed that the responses are not normally distributed about the mean or the full scale of 7 . It is skewed to the left which further shows that most of the responses were towards the direction of the value 1 on the responses scale. A policy on environmentally friendly purchases would compel the actions of the ICT personnel that would lead to a safe work place. Environmentally friendly purchases would lead to more efficient power use. 
An examination of Figure 2 column 1 reveals that $17.9 \%$ (strongly disagreed) of the respondents believe their organisations do not have a developed policy on employee's use of ICT in an energy efficient manner. At the same time $35.7 \%$ of the respodents disagreed to the being such a policy for employee's use of ICT in an energy efficient while $25.0 \%$ fairly disagreed. Amongst the respondents, $16.1 \%$ remained nuetral and $5.4 \%$ fairly agreed that their organisations had policy for employee's use of ICT in an energy efficient manner. With such a high percentage, $78.6 \%$, leaning towards the opinion that there is no policy for employee's use of ICT in an energy efficient manner, there are minimal chance that employees apply the ICT technologies in an energy efficient manner. Good ICT power use by employees would lead to major costs saving if the same consciousness is extended to having a policy on green supply chain management.

Findings in Figure 2 column 2 show that 14.3\% (strongly disagreed) of the respondents believe their organisations do not have a developed green chain supply management policy. At the same time $38.4 \%$ of the respodents disagreed to the being such a policy in their organisations while $29.5 \%$ fairly disagreed. Amongst the respondents, $15.2 \%$ remained nuetral. Only $1.8 \%$ fairly agree that there is a developed green chain supply management policy and $0.9 \%$ do agree to it being there. With such a high percentage of respondents being of the opinion that there may be no green chain supply management policy, there are minimal chance that green ICT is being implemented within the green chain supply management. A policy on green supply chain management would ensure that the actions of the ICT personnel would lead to a safe work place.

According to findings presented in Figure 2 column 3, 5.3\% (strongly disagreed) of the respondents believe their organisations do not have an end of ICT life management policy. At the same time $33.6 \%$ of the respodents disagreed to there being an end of ICT life management policy in their organisations while $36.3 \%$ fairly disagreed. Amongst the respondents $19.5 \%$ remained nuetral and 5.3\% fairly agreed that there being an end of ICT life management policy. This compliments what the interviewed respondents said. Most of them indicated that they would simply throw away the equipment if it is totally not working or they donated it out to schools without make any improvements or recycling it. With such a low percentage being of a strong opinion of there being an end of ICT life management policy, there are high chance that end of ICT life management is being practiced. This clearly points towards there being a low maturity level on end of ICT life management policy. A number of respondents indicated that most of the donation of ICT equipment consist those that had reached their end of life. Such kind of donations raises question on the nature of the organisations corporate social responsibilities policies they strive to adhere to.

Findings in Figure 2 column 4 indicates that $7.8 \%$ (strongly disagreed) of the respondents believe their organisations do not have a developed corporate social responsibility policy. At the same time $34.5 \%$ of the respodents disagreed to the being a corporate social responsibility policy in their organisations while $35.3 \%$ fairly disagreed. Amongst the respondents $10.3 \%$ remained nuetral. A total of $7.8 \%$ fairly agreed and $4.3 \%$ agreed to there being a corporate social responsibility policy. This was in line with what the interviewed respondents said. With such a high percentage being of the opinion that there may be a corporate social responsibility policy, there are minimal chance that corporate social responsibility is being practised. This clearly points to the low maturity level on ICT corporate social responsibility policy.

The maturity level seems to be fair on the environmental sustainability policy as can be observed from Figure 2 column 5. Findings show that $2.6 \%$ (strongly disagreed) of the respondents believe 
their organisations do not have a developed environmental sustainability policy. At the same time $22.8 \%$ of the respodents disagreed to the being an environmental sustainability policy in their organisations while $46.5 \%$ fairly disagreed. Amongst the respondents $15.8 \%$ remained nuetral. A total of $7.0 \%$ fairly agreed and $5.3 \%$ agreed to there being a devleloped policy on environmental sustainability. This finding correlate with the responses obtained in the interviews with respondents who majorly accepted that they have such a policy in the organisation but was not sure whether it touched on components of green ICT. Hardly did any respondents produce a copy of a green ICT environmental sustainability policy document. Many provided copies of the general organisational environmental policy documents which hardly had mention of ICT.

The findings on policy maturity were further analysed to establish the levels of green ICT policy readiness for the different policy dimensions in terms of means and standard deviations. The results of the analysis obtained are as presented in Table 1.

Table 1: ICT policy maturity means per case study

\begin{tabular}{|c|c|c|c|c|c|c|c|c|c|c|c|}
\hline \multicolumn{2}{|c|}{ Company where one is } & 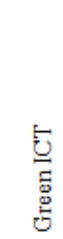 & 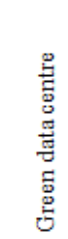 & 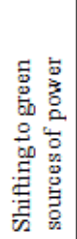 & 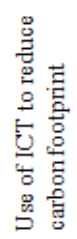 & 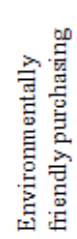 & 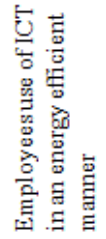 & 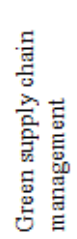 & 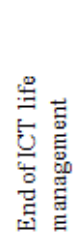 & 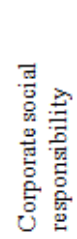 & 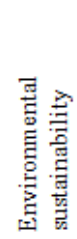 \\
\hline \multirow{3}{*}{$\begin{array}{l}\text { Manufac } \\
\text { turing } \\
\text { Industry }\end{array}$} & Mean & 1.82 & 1.69 & 1.62 & 2.03 & 2.03 & 2.63 & 2.28 & 2.77 & 3.73 & 3.03 \\
\hline & $\mathrm{N}$ & 28 & 29 & 29 & 30 & 30 & 30 & 29 & 30 & 30 & 30 \\
\hline & Std. Deviation & .723 & & .622 & 1.189 & 1.299 & .890 & .996 & 1.135 & 1.413 & 964 \\
\hline \multirow{3}{*}{$\begin{array}{l}\text { Regulato } \\
\mathrm{r}\end{array}$} & Mean & 1.50 & 1.69 & 1.50 & 1.77 & 1.91 & 2.32 & 2.33 & 2.87 & 2.58 & 3.29 \\
\hline & $\mathrm{N}$ & 26 & 26 & 26 & 26 & 22 & 22 & 24 & 23 & 26 & 24 \\
\hline & Std. Deviation & .583 & .679 & .510 & .815 & .811 & 1.086 & .868 & .757 & 1.065 & 1.042 \\
\hline \multirow{4}{*}{$\begin{array}{l}\text { Universit } \\
\text { y }\end{array}$} & Mean & 1.18 & 1.58 & 1.49 & 1.70 & 1.86 & 2.69 & 2.70 & 3.04 & 2.60 & 3.13 \\
\hline & $\mathrm{N}$ & 45 & 45 & 45 & 44 & 44 & 45 & 44 & 45 & 45 & 45 \\
\hline & Std. Deviation & & & & & & & & & & \\
\hline & & .387 & .690 & .506 & .954 & .765 & 1.276 & .904 & .976 & .963 & 1.198 \\
\hline \multirow{3}{*}{$\begin{array}{l}\text { Govem } \\
\text { ment } \\
\text { Office }\end{array}$} & Mean & 1.80 & 1.60 & 1.53 & 2.47 & 1.93 & 2.33 & 2.93 & 2.47 & 2.60 & 3.40 \\
\hline & $\mathrm{N}$ & 15 & 15 & 15 & 15 & 15 & 15 & 15 & 15 & 15 & 15 \\
\hline & Std. Deviation & .561 & .632 & .516 & 1.246 & .884 & 1.113 & 1.486 & .834 & 910 & 1.242 \\
\hline \multirow[t]{3}{*}{ Total } & Mean & 1.49 & 1.63 & 1.53 & 1.90 & 1.93 & 2.55 & 2.54 & 2.86 & 2.89 & 3.18 \\
\hline & $\mathrm{N}$ & 114 & 115 & 115 & 115 & 111 & 112 & 112 & 113 & 116 & 114 \\
\hline & Std. Deviation & 613 & .667 & .535 & 1.051 & 951 & 1.122 & 1.030 & .972 & 1.207 & 1.107 \\
\hline
\end{tabular}

From Table 1, it is clear that there is no significant difference between the policy maturity within the cases in the study. Also from the analysis given in Figure 1, it can be observed that the distribution of the responses is not normally distributed on the full scale of 7 . It is skewed to the left on the 7 Likert scale around the mean of 1.49 as can be observed from Figure 1. The responses on existences of policy on green ICT was mainly between strongly disagreeing and disagreeing. The responses were very consisted and not spread out. The responses had a standard deviation of 0.61 suggesting it to be less variable and hence giving the surety of the view held by ICT personnel on the lack of green ICT policy. All cases seem not to have any green ICT policy in place as the means are all below 2 (Manufacturing industry, 1.82; Regulator, 1.50; University, 
1.18; Government office, 1.80), that clearly indicate that the respondents strongly disagree with any being there. None of the case was able to provide a copy of their green ICT policy.

With regard to green data centre policy maturity, similar findings as for green policy were obtained. In all cases there were no green data policy documents. The means of respondents aside from the observation were all below 2 (Manufacturing industry, 1.69; Regulator, 1.69; University, 1.58; Government office, 1.60). This is in correspondence with strongly disagreeing that there was any such policy. Equally no case had a policy on shifting to green sources of power in place. No case produced a copy of the policy and the means of respondents were Manufacturing industry, 1.62; Regulator, 1.50; University, 1.49; and Government office, 1.53. With the responses standard deviation of 0.67 , it is clear that the responses were not spread out hence the opinion held by the ICT personnel being consistent and around a 1.6 mean suggesting disagreement with there being a policy shifting to green sources of power. The overall response is not normally distributed as can be seen from the curve in the Figure 33. With the responses standard deviation of 0.67 , it is clear that the responses are not spread out hence the opinion held by the ICT personnel being consistent and around a 1.6 mean suggesting disagreement of with there being a policy on green data centre management. This implies low maturity level on green data centre policy.

On policy with regard to use of ICT to reduce carbon footprint, though none was produced, Manufacturing industry and the government office had some written policy. They had means above 2 being 2.03 and 2.47 respectively. The Regulator and University have no policy on the same. They had means of 1.70 and 1.77 respectively. The cases did not have any policy on environmentally friendly purchasing produced. The mean from respondents on the aspect were Manufacturing industry, 2.03; Regulator, 1.91; University, 1.86; and Government office, 1.93. They all had values that correspond with disagree to existence of such a policy.

The policy maturity on the use of ICT to reduce carbon footprint was sought. The findings analyses of the same were as given in Table 1 and Figure 1 from which it can be observed that distribution of the responses is not normally distributed. The responses on existences of policy on using ICT to reduce carbon footprint is mainly taken as disagreement. The responses were very consisted and not spread out given the standard deviation of 1.05 suggesting it to be less variable and hence giving the surety of the view held by ICT personnel on the lack of policy on using green ICT to reduce carbon footprint. This finding correlates with the responses obtained in the interviews with respondents who majorly accepted that they did not have such a policy in the organisation. Hardly did any respondents produce a copy of the relevant policy document. According to the analysis of the findings presented in Table 1 and Figure 1 with reference to shifting to green source of power, it can be observed that the responses are skewed to the left on the Likert scale of 7 and also about a mean of 1.53. The responses therefore are not normally distributed as can be seen from the curve in the Figure 1. With the responses standard deviation of 0.54 , it is clear that the responses are not spread out hence the opinion held by the ICT personnel being consistent and around a 1.53 mean suggesting disagreement with there being a policy on shifting to green sources of power. This implies low maturity level on policy on shifting to green sources of power policy.

The following means were obtained for employees' use of ICT in an energy efficient manner policy maturity (manufacturing industry, 2.63; regulator, 2.32; University, 2.69; Government office, 2.33). It indicates that Manufacturing industry and University seem to be making effort 
towards having such a policy in place. Though there was no such policy in place, there were memos to that effect. With regard to green supply chain management policy, the government office is leading with a mean of 2.93 which however is still low corresponding to fairly disagree. The others have means of (Manufacturing industry, 2.28; Regulator, 2.33; and University, 2.70. University was leading the way when it came to end of ICT life management policy with a mean of 3.04 with the rest having Manufacturing industry, 2.77; Regulator, 2.87; and Government office, 2.47. These values are on the disagreement side. None of the cases had any written policy on end of ICT life management.

The organizations seemed have a slightly better performance on corporate social responsibility and environmental sustainability policy maturity where they recorded the means (Manufacturing industry, 3.73; Regulator, 2.58; University, 2.60; Government office, 2.60) and (Manufacturing industry, 3.03; Regulator , 3.29; University, 3.13; Government office, 3.40) respectively. Manufacturing industry and government offices were leading respectively in corporate social responsibility and environmental sustainability. The only policy where a hardcopy was produced was with regard to corporate social responsibility; however it was a general one and did not address the issue with specific emphasis of ICT.

The policy maturity means in the different cases were as presented in Figure 3.

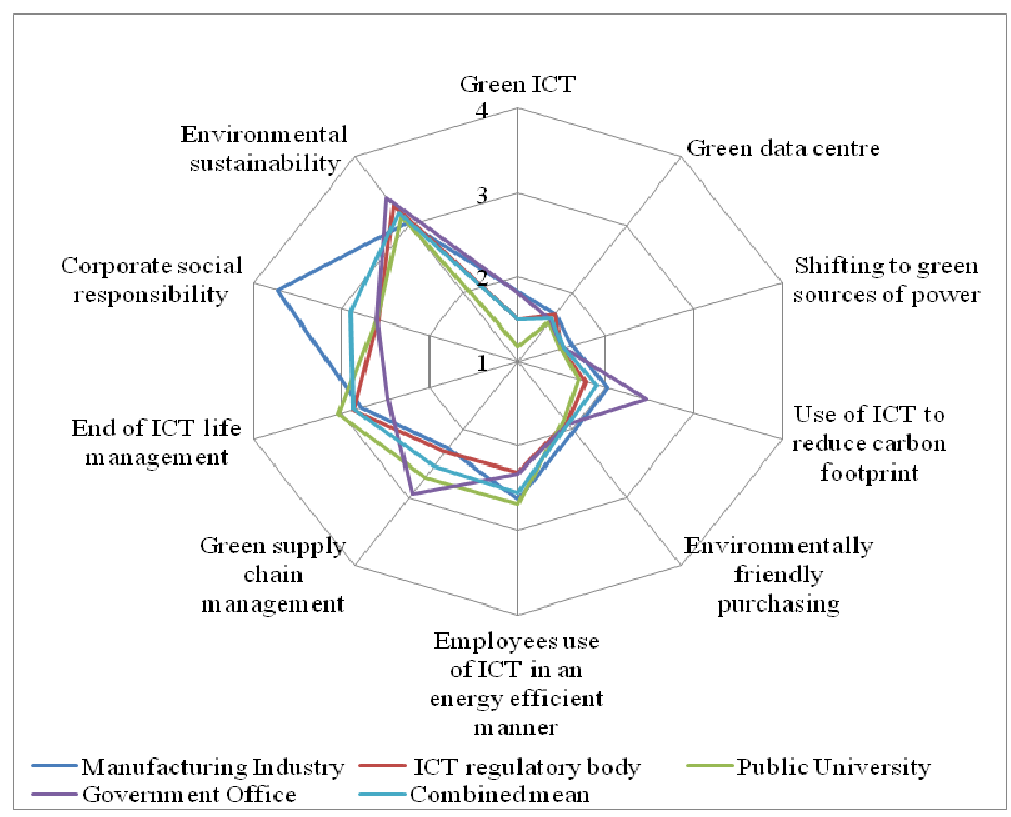

Figure 3: A comparison of case study green ICT policy maturity

Basically the green ICT policy maturity level was low in all cases though slightly on a better side on corporate responsibility and environmental sustainability. Manufacturing industry seemed to do better on the corporate social responsibility than any other case in the study. All cases had means of less than 4 on all policy dimensions assessed.

Based on the analysis discussed above, it may be said that Kenya's green ICT maturity is low on the overall as can be seen in Figure 4 when compared to other countries. 


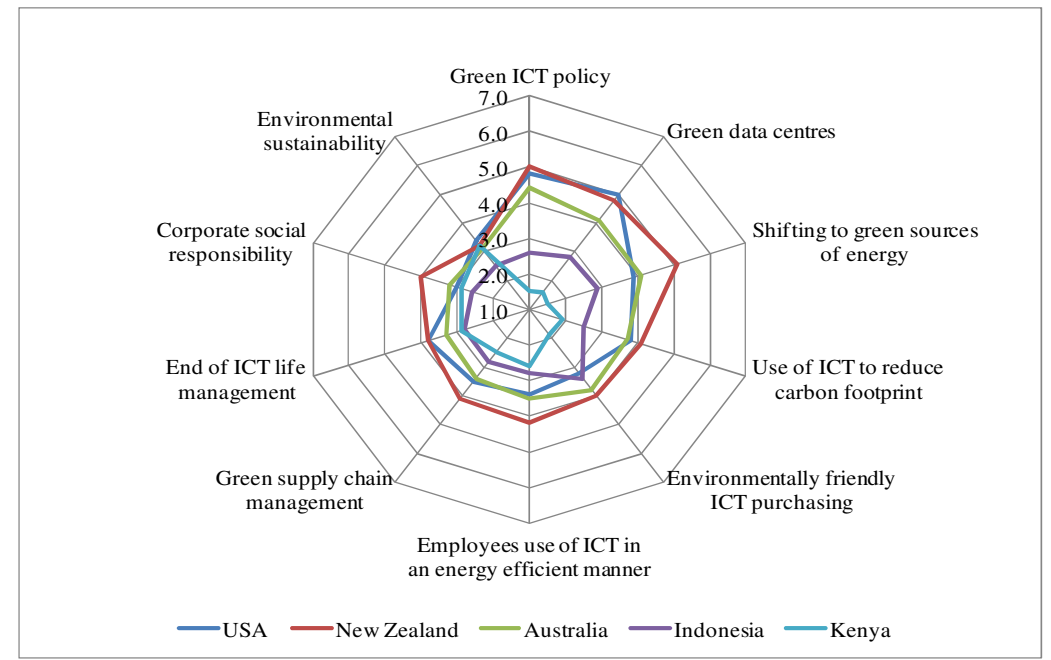

Figure 1: A comparison of countries green ICT policy maturity

Sources: Molla et al, 2009; Mariani \& Imam, 2012; Field data 2012

From Figure 4, it is clear that the green ICT policy maturity levels for developing economies (Kenya and Indonesia) are lower than those of the middle and developed economies (USA, Australia and New Zealand). The curves of Kenya and Indonesia are fairly close to the value 1 being to the lowest scale point.

\section{CONCLUSION}

The green ICT policy maturity levels in Kenya were assessed. The study assessed the maturity levels in line with the green data centre, shift to green sources of energy, use of ICT to reduce carbon footprint, and environmentally friendly purchasing. The study found out that green ICT policy maturity level in Kenya was low on the dimension in the previous sentence as well as employees use of ICT in an energy efficient manner, green supply chain management, end of ICT life management, corporate social responsibility and environmental sustainability policies.

\section{REFERENCE}

[1] Al Qur'an, N. M. (2010). How to use multiple case studies in International business research: Methodological aspects. International Review of Business Research Papers, 6 (2): 104-119.

[2] Bachour, N., \& Chesteen, L. (2010). Optimizing the Value of Green IT Projects within Organizations. Green technologies conference 2010 (pp. 1-10. Digital Object Identifier : 10.1109/GREEN.2010.5453804). IEEE.

[3] Baxter, P., \& Jack, S. (2008). Qualitative case study methodology: Study design and implementation for novice researchers. The Qualitative Report, 13 (4), 544-559. Retrieved from http://www.nova.edu/ssss/QR/QR13-4/baxter.pdf. 
International Journal of Computer Science, Engineering and Information Technology (IJCSEIT), Vol.9, No.3, June 2019

[4] Bryne, M. M. (2001). Evaluating the findings of qualitative research. AORN Journal, 73 (3): 703-706.

[5] Caetano, M., \& Amaral, D. (2011). Roadmapping for technology push and partnership: a contribution for open innovation environments. Technovation, 31, 320-335.

[6] Cooper, A. V., \& Molla, A. (2012). Developing green IT capability: An absorptive capacity perspective. Pacific asia Conference on Information Systems (p. p. T5_148doc). www.pacis2012.org/files/papers/pacis2012_T5_cooper_148.doc.

[7] Cooper, V., \& Molla, A. (2010). Conceptualizing Green IT Organzational Learning (GITOL). Green IT Working Paper Series. Paper No. 3/2010. Melbourne: School of Business Information Technology and Logistics, RMIT University.

[8] Daniels, J. (2009). Server virtualisation architecture and implementation. Fall Journal, 16 (1): 8-12.

[9] Eisenhardt, M. K. (1989). Building theories from case study research. The Academy of Management Review, 14 (4): 532-550.

[10] Habib, N. M., \& Imran, I. M. (2012). Role of Education and Training in the Successful Implementation of Business Process reengineering: A case of Public Sector of Khyber PakhtunKhwa (KPK). World Journal of Social Sciences, 2(2): 172-185.

[11] Hedman, J., \& Henningsson, S. (2011). Three strategies for green IT. IT Professionals. IEEE computer society, 13(1), 54-57.

[12] Herman, H., Shalaby, R. B., \& Bundgen, R. (2010). The greeing of Business. Frankfurt: Am Main: International GmgH.

[13] Jenkin, A. T., Webster, J., \& McShane, L. (2010). An agenda for "Green" information technology and systems research. Information and organisation.

[14] Kasomo, D. (2007). Research Methods in Humanities and Education. Eldoret: Zapf Chancery.

[15] Kothari, R. C. (2007). Research Methodology: Methods \& Techniques. New Delhi: New age international (P) limited, publishers.

[16] Maranto-Vargas, D., \& Rangel, T. R. (2007). Development of internal resources and capabilities as sources of differentiation of SME under increased global competition: A field study in mexico. Technicalogical forecasting and social change, 70:90-99.

[17] Ministry of Information \& Communications, _. (January 2006). National Information \& Communication (ICT) Policy. Nairobi: Government Printers.

[18] Molla, A., Cooper, A. V., \& Pittayachawan, S. (2009). IT and eco-sustainability: Developing and validating a green IT readiness model. Thirtieth International Conference on Information Systems, (p. P. 17).

[19] Munyua, W. (2010). Focus on ICTs and Environmental Sustainability. Global Information Society Watch 2010 (pp. 161-163). Kenya: In A. Finlay APC and HIVOS ISBN 92-95049-96-9.

[20] Mureithi, M., Waema, T., Wanjira, A., Finlay, A., \& Schlup. (2008). E-waste in Kenya: Baseline assessment. Proceeding of the 19th waste management conference of the IWMSA (Wastecon2008). Durban, South Africa: ISBN number: 978-0-620-40434-1. 
International Journal of Computer Science, Engineering and Information Technology (IJCSEIT), Vol.9, No.3, June 2019

[21] Murugesan, S. (2008). Harnessing Green IT: Principles and Practices. IT Professional IEEE computer Society, 10 (1): 24-33.

[22] Murugesan, s., \& Laplante, P. A. (2011). IT for a greener Planet. IT Professional IEEE Computer Society, 13 (1): 16-18.

[23] National Council for Science and Technology, .. (May 2010). Towards an effective Technology assessment system in Kenya. NCST No: 47. Nairobi: National Council for Science and Technology.

[24] Ogunyemi, A. A., \& Johnston, K. A. (2012). Exploring the roles of people, governance and technology in organizational readiness for emerging technologies. The African Journal of Information Systems, 4 (3): 100-119.

[25] Othman, I. M., Chan, T., Foo, E., Nelson, K., \& Timbrell, G. (2011). Barriers to Information Technology Governance Adoption: A preliminary Emprical Investigation. Proceedings of 15th International Business Information Management Association Conference (pp. 1771-1787). Cairo, Egypt: Queensland University of Technology.

[26] Patton, Q. M. (1990). Qualitative evaluation and research methods (2 ed). Newbury Park, Califonia: Sage Publication.

[27] Perry, C. (1998). Processes of a case study methodology for postgraduate research in marketing. European Journal of Marketing, 32 (9): 785-802.

[28] Philipson, G. (2010). A Green ICT Framework: Understanding and Measuring Green ICT. Australia: 2010 Connection Research Services Pty Ltd (ABN 47092657513.

[29] Rao, P., \& Holt, D. (2005). Do green supply chains lead to competitiveness and economic performance? International Journal of Operations \& Production Management, 25 (9): 898-916.

[30] Rowley, J. (2002). Using case studies in research. Management Research News, 25 (1): 16-27.

[31] Sameni, K. M., \& Khoshalhan, F. (July 2006). Analysis of Human Resource Development for Information Technology and E-Commerce in Iran. Tchnology Management for the Global Future (pp. (3) 1186-1202). IEEE: PICMET 2006 (ISBN: 1-890843-14-8).

[32] Sanad, A., Fidler, C., \& McBride, N. (March 23-24, 2010). Critical success factors for customer relationship management implementation. Proceedings of the 15th Annual UK Academy for Information Systems Conference (pp. 1-17). Oxford, AIS.

[33] Schmidt, N., \& Kolbe, L. M. (2011). Towards a contingency model for green IT Governance. AMCIS 2011 Proceedings.

[34] Schmidt, N., Erek, K., Kolbe, M. L., \& Zarnekow, R. (2010). Predictors of green IT adoption: Implications from an Emprical Investigation. AMCIS 2010 Proceedings., (p. available at: http://aisel.aisnet.org/amcis2010/367).

[35] Tenhunen, M. (2011). Conceptualizing and Measuring Green IT Readiness in Finnish Companies. Application Area: Electronic Invoice. Aalto University (Master's Thesis).

[36] The green IT report 2010. (2010). Green IT 2.0- People not technology. Retrieved from The green IT review: Http/www.thegreen itreview.com/2010/green-it-20.html 
International Journal of Computer Science, Engineering and Information Technology (IJCSEIT), Vol.9, No.3, June 2019

[37] Thomas, D. (2008). Easing the information System Headache Where People and Technology Intersect. Knowledge@Emory.

[38] Wabwoba F., Wanyembi G., Omuterema S. \& Omeino K. K. (2013). Green ICT readiness model for developing economies: case of Kenya. International Journal of Advanced Computer Science and Applications (IJACSA) 4(1): 51-65. ISSN 2156-5570 (online) 2158-107X (print) http://thesai.org/Downloads/Volume4No1/Paper_8-

Green_ICT_Readiness_Model_for_Developing_Economies_Case_of_Kenya.pdf

[39] Wanyembi, G. (2009). Improving ICT Management in public universities in Kenya. Answers to the problems arising from rapid introduction and use of the new technology. Deutschland: VDM Verlag Dr. Muller Aktiengsellschaft \& Co. Kg.

[40] Weill, P., \& Ross, W. J. (2004). IT governance: how top performers manage IT decision rights for superior results. Harvard Business Press.

[41] Willson, P., \& Polland, C. (2009). Exploring IT Governance in theory and practice in large multinational organisations in Australia. Information Systems management, 26 (2): 98-109.

[42] Winniford, M., Conger, S., \& Erickson-Harris, L. (2009). Confusion in the ranks. IT service management practice and terminology. Information Systems Management, 26(2): 153-163.

[43] Yin, K. R. (2009). Case study research: Design and Methods. Thousand Oaks, Califonia: Sage Publications. 